\title{
Tissue composition of the leg and meat quality of sheep fed castor bean hulls in replacement of tifton hay ${ }^{1}$
}

\author{
Stela Antas Urbano², Marcelo de Andrade Ferreira², Maria Inês Sucupira Maciel ${ }^{2}$, Wilson \\ Moreira Dutra Júnior ${ }^{2}$, Rafael de Paula Xavier de Andrade ${ }^{2}$, Daniel Cézar da Silva ${ }^{2}$
}

\author{
${ }^{1}$ Research project funded by $\mathrm{CNPq}$. \\ ${ }^{2}$ Universidade Federal Rural de Pernambuco, Recife, PE, Brasil.
}

\begin{abstract}
The effects of replacing Tifton hay with castor bean hulls $(0,33,66$ and $100 \%)$ on the leg tissue composition, chemical composition, physicochemical parameters and sensorial traits of sheep meat were studied. A total of 28 non-castrated sheep averaging seven months in age with an average initial weight of $19.5 \pm 4.3 \mathrm{~kg}$ were assigned to a randomized block design with four treatments and seven replicates and were slaughtered after 70 days of confinement. At slaughter, body weight and leg, muscle and bone weights decreased linearly, whereas the muscle-to-bone ratio increased linearly according to the treatments. There was a quadratic effect on yellow intensity (maximum of 8.05 with replacement of $54.5 \%$ ) and the percentage of cooking losses (minimum of $33.8 \%$ with replacement of $45.17 \%$ ). The treatment employed did not affect either the chemical composition or sensorial traits of the lamb meat. Although replacing Tifton hay with castor bean hulls alters the tissue composition of the leg as well as some physicochemical parameters of the meat, the sensory analysis indicated good acceptability of the meat, regardless of the inclusion of this byproduct.
\end{abstract}

Key Words: biodiesel, lamb, sensory attribute, tissue component

\section{Introduction}

Despite records of an increase in the productivity of the Brazilian sheep industry, especially in the northeast region of the country, the production chain involved in this activity is still being organized, which implies certain consequences for the sector, such as low consumption of lamb meat in Brazil compared with meat from other species. Increasing the per capita consumption of lamb meat undoubtedly depends on the improvement of the quality of the product that reaches the consumer.

One of the most important constraints in tropical livestock production systems is underfeeding due to limitations in both quantity and quality of feed (Atti \& Bem Salem, 2008; Mendieta-Araico et al., 2011). The agroindustrial residues appear as an alternative in ruminant feed during periods of food shortage (Klopfenstein et al., 2008; Molina-Alcaide \& Yáñez-Ruiz, 2008).

The consumer market currently shows increased demand for quality in meat characteristics, which makes it necessary to understand the meat quality characteristics (Bressan et al., 2001). In addition, a carcass should exhibit high proportions of muscle and sufficient fat content in its composition to provide meat with sensory properties that are adequate for the preferences of the consumer market. Consequently, research on tissue composition is necessary (Silva Sobrinho et al., 2005b).

The downward trend in the use of petroleum-based energy sources in Brazil has been encouraging the production of renewable energy, like biodiesel(Brunschwig et al., 2012). The cultivation of castor bean allows the establishment of semi-arid regions in this chain of biofuel production (Gabriella et al., 2007; Cesar \& Batalha, 2010). All oil extraction processes produce residues; in the case of castor bean oil, the main ones are the crust, the press cake and meal (Silva et al., 2010).

Considering the importance of feeding in the production and in the general characteristics of lamb meat, there is a need for studies on the influence of feeding on the quality of lamb meat with the goal of detecting alternative feeding systems that are adaptable to the rearing conditions in different production systems (Madruga et al., 2005).

The objective of this research was to evaluate the effects of replacement of Tifton hay by castor bean hulls in the diet of sheep on the tissue composition of the lamb leg as well as on the chemical composition, physicochemical parameters and sensory parameters of the meat. 


\section{Material and Methods}

The experiment was conducted in the goat farming group within the Department of Animal Science of the Universidade Federal Rural de Pernambuco (UFRPE), which is located in Recife, Pernambuco State, Brazil in the physiographic microregion of the Atlantic coast that belongs to the Metropolitan Region of Recife.

A total of 28 undefined breed pattern (UBP) sheep were used. All sheep were seven months old, with an initial weight of $19.5 \pm 4.3 \mathrm{~kg}$, and were confined to individual suspended pens with slatted floors. They were provided with feeders and drinking troughs. After being weighed and identified, treated against endo- and ectoparasites, and vaccinated against clostridia, the animals underwent a 30-day period of adaptation to the new facilities and to the way in which they were being handled. All animal handling practices followed the recommendations of the National Council for Control of Animal Experimentation (Conselho Nacional de Controle da Experimentação Animal, CONCEA) for the protection of animals used for experimental and other scientific purposes.

The experimental diets were isoprotein, with the base diet formulated to meet the requirements to maintain the animals at $24 \mathrm{~kg}$ and to allow for an average weight gain of $180 \mathrm{~g}$ /day according to the recommendations of the NRC (1985). The diets included replacement of Tifton hay with castor bean hulls at rates of $0,33,66$, and $100 \%$ (Table 1 ). Feeding was performed twice a day (8:00 a.m. and 3:00 p.m.) in the form of a total mixed ration, ad libitum, with water always available for the animals. The uneaten feed was collected daily and weighed to adjust the food supply and to

Table 1 - Ingredients and chemical composition of the experimental diets

\begin{tabular}{lcccc}
\hline & \multicolumn{4}{c}{ Substitution rate (\%) } \\
\cline { 2 - 5 } Ingredients (g/kg DM) & 0 & 33 & 66 & 100 \\
\hline Spineless cactus & 400 & 400 & 400 & 400 \\
Tifton hay & 300 & 200 & 100 & 0 \\
Castor bean hull & 0 & 99 & 198 & 297 \\
Soybean meal & 185 & 185 & 185 & 185 \\
Ground corn & 100 & 100 & 100 & 100 \\
Sodium chloride & 05 & 05 & 05 & 05 \\
Mineral mix & 10 & 10 & 10 & 10 \\
Urea & 0 & 01 & 02 & 03 \\
Chemical composition & & & & \\
Dry matter (g/kg) & 249.9 & 250.1 & 250.2 & 250.4 \\
Crude protein (g/kg DM) & 139.4 & 138.7 & 138.1 & 137.5 \\
Ether extract (g/kg DM) & 16.0 & 15.1 & 14.1 & 13.1 \\
Mineral matter (g/kg DM) & 106.8 & 104.3 & 101.9 & 99.4 \\
Neutral detergent fiber (g/kg DM) & 404.9 & 402.3 & 399.6 & 397.0 \\
Acid detergent fiber (g/kg DM) & 167.4 & 178.4 & 189.5 & 200.5 \\
TDN (g/kg DM) & 626.1 & 624.9 & 566.0 & 561.1 \\
\hline
\end{tabular}

DM - dry matter; TDN - total digestible nutrients. calculate the intake of dry matter. Weighing was performed every 14 days, with prior fasting for 16 hours, from the beginning of the experiment until slaughter.

To estimate the total digestible nutrients (TDN) in the feed, a digestibility assay was performed 40 days after the beginning of the experiment. The estimated TDN value was calculated using the following equation described by Weiss (1999): TDN = DCP (digestible crude protein) + DEE (digestible ether extract) $* 2.25+$ DNFC (digestible nonfibrous carbohydrate) + DNDF (digestible neutral detergent fiber $)$, where $\mathrm{DCP}=(\mathrm{CP}$ ingested $-\mathrm{CP}$ feces $) ; \mathrm{DEE}=(\mathrm{EE}$ ingested $-\mathrm{EE}$ feces $) ; \mathrm{DNFC}=(\mathrm{NFC}$ ingested $-\mathrm{NFC}$ feces $)$; and DNDF $=($ NDF ingested - NDF feces $)$.

After 70 days in addition to the adaptation period, the animals were fed a purely liquid diet for 16 hours. Then, immediately before slaughter, they were weighed to obtain their body weight at slaughter (BWS). The stunning for humane slaughter of animals followed the rules of Instruction number 3 of 07/17/2000, so the method employed was concussion, rather than penetration (Brazil, 2000).

After skinning and evisceration, the head (sectioned at the atlo-occipital joint) and the feet (sectioned at the metacarpal and metatarsal joints) were removed from each animal, and the carcasses were placed in a refrigerated chamber and left to cool for 24 hours at $\pm 4{ }^{\circ} \mathrm{C}$ hanging from hooks by the Achilles tendon with the metatarsal joints spaced $17 \mathrm{~cm}$ apart. After the refrigeration period, the carcasses were cut in half, and the left half of the carcasses was weighed and cut into seven anatomical regions according to the methodology adapted by Cezar \& Sousa (2007), resulting in the following commercial meat cuts: neck, shoulder, leg, loin, true ribs, false ribs and sawcut. The adaptation of the methodology consisted of the division the ribs in true ribs and false ribs.

The left leg of each animal was vacuum-packed in a high-density polyethylene bag and frozen at $-18{ }^{\circ} \mathrm{C}$ to evaluate its tissue composition. The composition was determined using the methodology described by Brown \& Williams (1979) in which the 28 left legs, which had been previously stored and were then gradually thawed while being kept at a temperature of approximately $4{ }^{\circ} \mathrm{C}$ for 24 hours, were dissected. During the dissections, the five main muscles associated with the femur (biceps femuris, semimembranosus, semitendinosus, quadriceps femoris and adductor) were removed intact and then weighed to calculate the leg muscularity index according to the following formula: $\mathrm{LMI}=\sqrt{ }(\mathrm{W} 5 \mathrm{M} / \mathrm{FL}) / \mathrm{FL}$, where $\mathrm{W} 5 \mathrm{M}$ represents the weight of the five muscles $(\mathrm{g})$ and $\mathrm{FL}$ is femur length $(\mathrm{cm})$ (Purchas et al., 1991). 
A qualitative analysis of the meat was performed using the right loins of each animal, which had been vacuumpacked and frozen at $-18{ }^{\circ} \mathrm{C}$. Cooking losses, shearing force and color were determined according to the methodology described by Wheeler et al. (1993).

The water-holding capacity (\%) was determined according to the methodology proposed by Sierra (1973).

The percentage composition was calculated for the semimembranosus muscle, which was crushed and homogenized in a blender and then dried for subsequent determination of moisture, crude protein, ether extract and ash according to the methods described by the AOAC (2000).

For sensory analysis, the left loins (longissimus lomborum) were used. They were cooked according to the methodology proposed to determine cooking losses. A total of 50 untrained testers who enjoy lamb meat were invited to participate. An affective acceptance test was conducted in individual chambers using a seven-point hedonic scale that considered the attributes of flavor, juiciness, aroma, color and texture. The seven points of the scale were as follows: 1 - very strongly disliked, 2 - strongly disliked, 3 - slightly disliked, 4 - neither liked nor disliked, 5 - slightly liked, 6 - strongly liked and 7 - very strongly liked. Each tester was served a sample (approximately 12 to $15 \mathrm{~g}$ ) of meat from each treatment in a coded (three digits) disposable container. To remove any residual taste in between samples, water at room temperature was served along with an unsalted cracker.

Analysis of the variables was performed by adopting a model relative to the completely randomized design, according to the following model:

$$
Y_{i j}=\mu+T_{i}+\beta\left(X_{i j}-X\right)+e_{i j}
$$

where $\mathrm{Y}_{\mathrm{ij}}=$ observed value of the dependent variable; $\mu=$ overall mean; $\mathrm{T}_{\mathrm{i}}=$ effect of treatment $\mathrm{i}(\mathrm{i}=1$ to 4$) ; \beta\left(\mathrm{X}_{\mathrm{ij}}-\mathrm{X}\right)$ $=$ covariate effect (initial weight); and $\mathrm{e}_{\mathrm{ij}}=$ experimental error. The data were tabulated and subsequently subjected to analysis of covariance using the PROC MIXED procedures of SAS statistical package (Statistical Analysis System, version 9.1).

\section{Results and Discussion}

The total digestible nutrient intake (TDNI), body weight at slaughter (BWS) and weight of the entire leg, muscles, and bones linearly decreased with increasing replacement of Tifton hay by castor bean hulls (Table 2). No influence of the replacement $(\mathrm{P}>0.05)$ was observed regarding the dry matter intake (DMI) or the weight of subcutaneous fat, intermuscular fat, or total fat. Additionally, no effect was seen on the weight of other tissues, the muscle:fat ratio, the subcutaneous:intermuscular fat ratio, or the leg muscularity index (LMI). The muscle:bone ratio increased linearly with increasing replacement. Furthermore, an effect of the replacement on the yield of bones and other tissues was observed, which decreased linearly (Table 3 ). The linear decrease observed for the weight of the entire leg and BWS could be explained by the decrease in energetic intake (Table 2). As muscles and bones constitute the greatest percentage of the leg composition, the difference observed between the weights of the legs consequently implied a relevant difference between these groups.

For each percentage point of replacement of hay by castor bean hulls, there was a decrease of $2.2041 \mathrm{~g}$

Table 2 - Dry matter and total digestible nutrient intake and tissue composition of the left leg of sheep fed castor bean hulls in replacement of Tifton hay

\begin{tabular}{|c|c|c|c|c|c|c|c|c|}
\hline \multirow{2}{*}{ Item } & \multicolumn{4}{|c|}{ Substitution rate $(\%)$} & \multirow{2}{*}{$\mathrm{CV}$} & \multicolumn{2}{|c|}{ Effect } & \multirow{2}{*}{$\mathrm{r}^{2}$} \\
\hline & 0 & 33 & 66 & 100 & & Linear & Quadratic & \\
\hline DMI (kg/day) & 0.95 & 0.93 & 0.97 & 0.86 & 13.30 & NS & NS & - \\
\hline TDNI (kg/day) & 0.64 & 0.63 & 0.60 & 0.52 & 17.45 & $*$ & NS & 0.83 \\
\hline BWS (kg) & 32.84 & 31.59 & 30.37 & 28.67 & 5.32 & $* * *$ & NS & 0.99 \\
\hline Entire leg (g) & 2388.42 & 2272.92 & 2167.94 & 2046.06 & 8.00 & $* * *$ & NS & 0.99 \\
\hline Muscles (g) & 1583.11 & 1491.90 & 1440.75 & 1355.54 & 10.51 & $* *$ & NS & 0.99 \\
\hline Bones (g) & 450.08 & 431.08 & 382.26 & 359.29 & 11.70 & $* * *$ & NS & 0.97 \\
\hline Subcutaneous fat (g) & 129.11 & 113.54 & 128.38 & 116.47 & 29.99 & NS & NS & - \\
\hline Intermuscular fat (g) & 100.86 & 105.71 & 96.20 & 85.78 & 21.06 & NS & NS & - \\
\hline Total fat $(\mathrm{g})$ & 229.97 & 219.25 & 224.58 & 202.25 & 22.92 & NS & NS & - \\
\hline Other tissues (g) & 125.27 & 130.70 & 120.36 & 128.98 & 12.43 & NS & NS & - \\
\hline Muscle:Bones & 3.55 & 3.46 & 3.77 & 3.80 & 7.99 & $*$ & NS & 0.66 \\
\hline Muscle:Fat & 7.73 & 7.29 & 6.68 & 7.50 & 28.63 & NS & NS & - \\
\hline $\mathrm{SF}: \mathrm{IF}$ & 1.24 & 1.06 & 1.31 & 1.36 & 28.24 & NS & NS & - \\
\hline Leg muscularity index & 0.38 & 0.39 & 0.38 & 0.38 & 5.20 & NS & NS & - \\
\hline
\end{tabular}

$\mathrm{CV}$ - coefficient of variation; $\mathrm{r}^{2}$ - coefficient determination.

NS - not significant.

$* \mathrm{P}<0.05 ; * * \mathrm{P}<0.01 ; * * * \mathrm{P}<0.001$

DMI - dry matter intake; TDNI - total digestible nutrient intake; BWS - body weight at slaughter. 
Table 3 - Yield of tissue components of the left leg of sheep fed castor bean hulls in replacement of Tifton hay

\begin{tabular}{|c|c|c|c|c|c|c|c|c|}
\hline \multirow{2}{*}{ Item $(\%)$} & \multicolumn{4}{|c|}{ Substitution rate $(\%)$} & \multirow{2}{*}{$\mathrm{CV}$} & \multicolumn{2}{|c|}{ Effect } & \multirow{2}{*}{$r^{2}$} \\
\hline & 0 & 33 & 66 & 100 & & Linear & Quadratic & \\
\hline Muscles & 66.12 & 65.64 & 66.37 & 66.28 & 3.72 & NS & NS & - \\
\hline Bones & 18.90 & 19.04 & 17.77 & 17.57 & 7.45 & $*$ & NS & 0.80 \\
\hline Subcutaneous fat & 5.43 & 4.90 & 5.88 & 5.69 & 33.13 & NS & NS & - \\
\hline Intermuscular fat & 4.28 & 4.59 & 4.45 & 4.20 & 21.22 & NS & NS & - \\
\hline Total fat & 9.71 & 9.49 & 10.33 & 9.88 & 25.37 & NS & NS & - \\
\hline Other tissues & 5.28 & 5.84 & 5.53 & 6.26 & 11.45 & $*$ & NS & 0.66 \\
\hline
\end{tabular}

$\mathrm{CV}$ - coefficient of variation; $\mathrm{r}^{2}$ - coefficient determination.

NS - not significant.

$* \mathrm{P}<0.05$.

$(0.14 \%)$ in the weight of the muscles, whereas the decrease in the weight of the bones was $4.2591 \mathrm{~g}(0.94 \%)$. This result explains the linear increase observed in the muscle: bone ratio, rather than a decrease, as the decrease in the denominator of the ratio was always greater than that of the numerator, resulting in a greater value.

Carvalho \& Medeiros (2010) investigated $1 / 2$ Texel $+1 / 2$ UBP sheep fed diets containing different levels of energy and did not observe variations in the weight of muscles, bones or fat. However, they showed that as the amount of energy increased, the percentage of muscle decreased, whereas the percentage of fat increased, which was not found in this study. Gerrard \& Grant (2006) indicated that following the development of the skeletal system, bone growth is minimal. In contrast, muscular growth increases dramatically and quickly becomes the largest component of the carcass, whereas the amount fat is very low at birth and remains so until muscle growth decreases or reaches a plateau. Because there was no variation observed with respect to fat in this study, it can be inferred that the animals were slaughtered before fat was deposited, i.e., before reaching a plateau in muscular growth. This result should be evaluated as being positive considering the current trend of reducing the amount of calories consumed in the human diet (Pérez et al., 2002).

A bone yield similar to that found here (18\%), though associated with a lower muscle yield (50.9\%) and a much higher fat yield (30\%) was found by Carvalho \& Medeiros (2010) for a lower-quality carcass than was observed in this research.

Working with wet waste from a brewery and substituting different levels of corn and soybeans and, consequently, different levels of energy in the diet of Texel breed sheep, Carvalho \& Brochier (2008) observed very similar results to those found in this study, finding a decrease in body weight at slaughter, a decrease in the weight of the part to be dissected, and consequently, a decrease in the weights of the muscle and bone components. In terms of the yield of tissue components, these authors obtained lower values than were obtained here for muscle yield (58.4\%) and higher values for bones (27.4\%) and fat (14.2\%).

Marques et al. (2007) examined Santa Ines sheep slaughtered after 70 days of confinement. These sheep exhibited an average body weight at slaughter of $30 \mathrm{~kg}$, and lower values were found for muscle yield (63.41\%), total fat yield (6.98\%), yield of other tissues (4.64\%), leg muscularity (0.34) and the muscle:bone ratio (2.58), with higher values obtained only for bone yield $(25.00 \%)$.

The leg muscularity index (LMI) reflects the proportion of meat in the carcass. There was no variation in the LMI, even though variation was found in the weight of muscles and in the muscle:bone ratio. However, Silva Sobrinho et al. (2005b) claimed that measurements of muscularity may not differ even when there are differences in muscle quantity, which is the result of variation in bone length with age, even within a single breed. The values found for this variable are close to those found by Garcia et al. (2003), thus indicating that a satisfactory proportion of muscle was obtained for the carcasses in this study (66\% muscle).

In a study on Santa Ines sheep slaughtered with very similar live weights to those of the sheep studied here, Marques et al. (2007) found values between 0.31 and 0.36 .

With respect to the subcutaneous:intermuscular fat ratio, Huidobro \& Cañeque (1994) stated that a high value may indicate a desirable product for the market, as subcutaneous fat guarantees good conservation of the carcass under refrigeration. The value found here was less than that obtained by Garcia et al. (2003) (1.82 compared with 2.58) but was close to the 1.37 obtained by Silva Sobrinho (1999).

The percentage yield of the tissue components reflected a carcass of good quality that is appropriate for the market, as it showed a high proportion of muscle, a low percentage of tissues that are of no interest to the consumer, and an intermediate fat percentage, which can be expressed by the muscle:fat ratio (7.40), implying desirable palatability.

In terms of the physicochemical parameters of the meat, there was an influence of the replacement on the yellow intensity $\left(b^{*}\right)$ in the coloring of the meat and cooking 
losses, with a quadratic effect detected for these parameters. For $b^{*}$, a maximum of 8.05 was observed, which occurred with $54.5 \%$ replacement. Regarding cooking losses, the minimum value observed was $33.8 \%$ when $45.17 \%$ of Tifton hay was replaced by castor bean hulls. The luminosity $\left(\mathrm{L}^{*}\right)$, red intensity $\left(\mathrm{a}^{*}\right)$, and water-holding capacity of the meat were not influenced by the replacement $(\mathrm{P}>0.05)$ (Table 4$)$.

In examining the influence of weight at slaughter, Sañudo et al. (1996) also observed that the yellow intensity $\left(b^{*}\right)$ exhibited a quadratic effect, with the intermediate weight group displaying higher values, as was found in this study. According to Pinheiro (2006), the color of meat is influenced by luminosity and red intensity, whereas yellow intensity is more significant with respect to the color of fat.

The results for shearing force are very close to those reported by Bressan et al. (2001), which varied between 2.3 and $3.2 \mathrm{~kg} / \mathrm{cm}^{2}$ (Table 4). Vieira et al. (2010) detected variation between 4.6 and $5.3 \mathrm{~kg} / \mathrm{cm}^{2}$ when evaluating the longissimus dorsi. For meat to be within the acceptable range of softness, Bianchini et al. (2007) stated that the average shearing force values should be below $5 \mathrm{~kg} / \mathrm{cm}^{2}$. Therefore, the variation from 2.3 to 3.34 obtained in this study allows for classifying the meat as tender.

Using the same methodology to determine waterholding capacity, Santos Silva et al. (2002) found an average value of $39 \%$ for this parameter when animals were slaughtered at an average weight of $30 \mathrm{~kg}$. According to Osório et al. (2009), meat with a lower water-holding capacity will rapidly lose its juice during cooking, which would be aggravated by the pre-concentration of collagen at $65-70{ }^{\circ} \mathrm{C}$ and the denaturation of protein, reaching losses of approximately $50 \%$. Furthermore, there would be decreases in the nutritional value, as the lost liquid contains water-soluble substances, proteins and vitamins. Based on the review of the results reported by these authors, the values found here for water-holding capacities should not be considered low, as the values for cooking losses and the chemical composition of the meat are consistent with those found in the current literature.
The values for cooking losses are close to the average $38.4 \%$ obtained by Silva Sobrinho et al. (2005a), who slaughtered sheep at ages between 150 and 300 days. Pinheiro (2006) reported cooking losses of $46.44 \%$, which is much higher than the values obtained in this study (Table 4). Bonagurio et al. (2003) found an average value of $36.12 \%$, which is consistent with the data obtained in this study.

There was no influence of the replacement of Tifton hay by castor bean hulls on the chemical composition of the meat ( $\mathrm{P}>0.05$; Table 5).

Studying the chemical composition of lamb meat, Zapata et al. (2001) found average values for moisture, ash, proteins, and lipids of $76.15,1.08,19.32$ and $2.18 \mathrm{~g} / 100 \mathrm{~g}$, respectively. Thus, the results found in this study for proteins, ash and lipids are above the average values found by these authors.

Russo et al. (1999) showed that weight at slaughter influences the chemical composition of meat, as heavier sheep deposit more fat and, as a result, exhibit a lower amount of water and protein in their meat. Bonagurio et al. (2004) examined the composition of pure Santa Ines sheep and their crossbreeds slaughtered at different weights and came to a similar conclusion: with an increase in slaughter weight, there is a decrease in the amount of moisture, which is associated with a tendency for the reduction in the amount of crude protein. However, this effect was not observed in this study, where it was found that variation in weight at slaughter did not influence the chemical composition of the meat.

In the affective test of acceptance, no influence of the replacement of Tifton hay by castor bean hulls was found with respect to color, aroma, flavor, texture or juiciness $(\mathrm{P}>0.05)$. Therefore, it can be inferred that despite the variation that existed in some physicochemical parameters, this variation was not large enough to be perceived by the consumer (Table 6).

The results of the affective test of acceptance are in accordance with the results obtained in the physicochemical

Table 4 - Physicochemical parameters of the meat of sheep fed castor bean hulls in replacement of Tifton hay

\begin{tabular}{|c|c|c|c|c|c|c|c|c|}
\hline \multirow{2}{*}{ Item } & \multicolumn{4}{|c|}{ Substitution rate $(\%)$} & \multirow{2}{*}{$\mathrm{CV}$} & \multicolumn{2}{|c|}{ Effect } & \multirow{2}{*}{$\mathrm{r}^{2}$} \\
\hline & 0 & 33 & 66 & 100 & & Linear & Quadratic & \\
\hline $\mathrm{L}^{*}$ & 40.62 & 40.94 & 41.45 & 41.01 & 5.53 & NS & NS & - \\
\hline$a^{*}$ & 11.22 & 12.23 & 11.26 & 11.42 & 9.59 & NS & NS & - \\
\hline$b^{*}$ & 6.63 & 8.19 & 7.58 & 7.44 & 8.03 & NS & $* * *$ & 0.72 \\
\hline Shearing force $\left(\mathrm{kg} / \mathrm{cm}^{2}\right)$ & 3.34 & 2.30 & 2.94 & 2.52 & 12.72 & NS & NS & - \\
\hline Cooking losses (g/100 g) & 37.09 & 32.94 & 35.32 & 37.90 & 7.08 & NS & $* *$ & 0.86 \\
\hline Water-holding capacity (\%) & 31.00 & 30.00 & 32.77 & 30.18 & 13.39 & NS & NS & - \\
\hline
\end{tabular}

$\mathrm{CV}$ - coefficient of variation; $\mathrm{r}^{2}$ - coefficient determination.

NS - not significant.

$* \mathrm{P}<0.05$; * $\mathrm{P}<0.01$;*** $\mathrm{P}<0.001$. 
Table 5 - Chemical composition of the meat of lambs fed castor bean hulls in replacement of Tifton hay

\begin{tabular}{|c|c|c|c|c|c|c|c|}
\hline \multirow{2}{*}{ Item $(\mathrm{g} / 100 \mathrm{~g})$} & \multicolumn{4}{|c|}{ Substitution rate $(\%)$} & \multirow{2}{*}{$\mathrm{CV}$} & \multicolumn{2}{|c|}{ Effect } \\
\hline & 0 & 33 & 66 & 100 & & Linear & Quadratic \\
\hline Moisture & 76.01 & 76.42 & 75.90 & 75.73 & 1.22 & NS & NS \\
\hline Ash & 1.07 & 1.05 & 1.07 & 1.09 & 4.24 & NS & NS \\
\hline Crude protein & 21.76 & 22.28 & 21.84 & 21.82 & 6.93 & NS & NS \\
\hline Ether extract & 2.45 & 2.53 & 2.47 & 2.06 & 19.68 & NS & NS \\
\hline
\end{tabular}

$\mathrm{CV}$ - coefficient of variation.

NS - not significant.

Table 6 - Sensory attributes ${ }^{1}$ of the meat of lambs fed castor bean hulls in replacement of Tifton hay

\begin{tabular}{|c|c|c|c|c|c|c|c|}
\hline \multirow{2}{*}{ Parameter } & \multicolumn{4}{|c|}{ Substitution rate $(\%)$} & \multirow{2}{*}{$\mathrm{CV}$} & \multicolumn{2}{|c|}{ Effect } \\
\hline & 0 & 33 & 66 & 100 & & Linear & Quadratic \\
\hline Color & 4.92 & 5.16 & 4.70 & 5.10 & 16.81 & NS & NS \\
\hline Aroma & 5.10 & 5.16 & 4.88 & 5.16 & 16.30 & NS & NS \\
\hline Flavor & 5.44 & 5.16 & 4.94 & 5.10 & 22.09 & NS & NS \\
\hline Texture & 5.78 & 5.68 & 5.30 & 5.52 & 17.64 & NS & NS \\
\hline Juiciness & 5.48 & 5.56 & 4.98 & 5.30 & 20.15 & NS & NS \\
\hline
\end{tabular}

$\mathrm{CV}$ - coefficient of variation.

NS - not significant.

${ }^{1}$ Score: 1 - very strongly disliked; 7 - very strongly liked.

evaluation of the meat. The scores attributed to flavor reflect the balance of the tissue components as well as the presence of a sufficient amount of fat to make the meat palatable while remaining healthful and nutritious. The scores given to texture reinforce the results of Bianchini et al. (2007), who classify meat as tender when shearing force values are less than $5 \mathrm{~kg} / \mathrm{cm}^{3}$.

With respect to juiciness, the good scores obtained were in agreement with the values for water-holding capacity, as this parameter is closely related to the attribute in question. According to Osório et al. (2009), a low water-holding capacity will certainly result in dry meat when chewed, which would consequently be more difficult to cut, but this result was not observed in our sensory analysis.

According to Teixeira et al. (1987), for a product to be considered acceptable in terms of its sensory properties, it must present an index of acceptability of at least $70 \%$. In this study, the lamb meat achieved good acceptability in all of the sensory attributes studied, since over $70 \%$ of the scores assigned were equal to or greater than 5 , so they could be considered acceptable.

\section{Conclusions}

Replacement of Tifton hay by castor bean hulls reduces the weight of tissue components of the lamb leg, with negligible changes in chemical composition and physicochemical parameters of meat. The affective test of acceptance indicates good acceptance of the meat, regardless of the inclusion of the alternative ingredient.

\section{References}

ASSOCIATION OF OFFICIAL ANALYTICAL CHEMISTRY AOAC. Official methods of analysis of AOAC International. 19.ed. Washington, D.C.: AOAC International, 2000.

ATTI, N.; BEM SALEM, H. Compensatory growth and carcass composition of Barbarine lambs receiving different levels of feeding with partial replacement of the concentrate with feed blocks. Animal Feed Science and Technology, v.147, p.265-277, 2008.

BIANCHINI, W.; SILVEIRA, A.C.; JORGE, A.M. et al. Efeito do grupo genético sobre as características de carcaça e maciez da carne fresca e maturada de bovinos superprecoces. Revista Brasileira de Zootecnia, v.36, p.2109-2117, 2007.

BONAGURIO, S.; PEREZ, J.R.O.; GARCIA, I.F.F. et al. Qualidade da carne de cordeiros Santa Inês puros e mestiços com Texel abatidos com diferentes pesos. Revista Brasileira de Zootecnia, v.32, p.1981-1991, 2003.

BONAGURIO, S.; PEREZ, J.R.O.; GARCIA, I.F.F. et al. Composição centesimal da carne de cordeiros Santa Inês puros e de seus mestiços com Texel abatidos com diferentes pesos. Revista Brasileira de Zootecnia, v.33, p.2387-2393, 2004.

BRASIL. Ministério da Agricultura, Pecuária e do Abastecimento (MAPA). Secretaria da Defesa Agropecuária (SDA). Departamento de Inspeção de Produtos de Origem Animal (DIPOA). Divisão de Normas Técnicas. Instrução Normativa n.3, de 17 de janeiro de 2000. Lex: Diário Oficial da União de 24 de janeiro de 2000. Seção 1, p.14-16. Brasília, 2000.

BRESSAN, M.C.; PRADO, O.V.; PÉREZ, J.R.O. et al. Efeito do peso ao abate de cordeiros Santa Inês e Bergamácia sobre as características físico-químicas da carne. Ciência e Tecnologia de Alimentos, v.21, p.293-303, 2001.

BROWN, A.J.; WILLIAMS, D.R. Sheep carcass evaluation: measurement of composition using a standardized butchery method. Langford: Agricultural Research Council; Meat Research Council, 1979. 16p.

BRUNSCHIWIG, C.; MOUSSAVOU, W.; BLIN, J. Use of bioethanol for biodiesel production. Progress in Energy and Combustion Science, v.38, p.283-301, 2012.

CARVALHO, S.; BROCHIER, M.A. Composição tecidual e centesimal e teor de colesterol da carne de cordeiros terminados em confinamento com dietas contendo níveis crescentes de resíduo úmido de cervejaria. Ciência Rural, v.38, p.2023-2028, 2008. 
CARVALHO, S.; MEDEIROS, L.M. Características de carcaça e composição da carne de cordeiros terminados em confinamento com dietas com diferentes níveis de energia. Revista Brasileira de Zootecnia, v.39, p.1295-1302, 2010.

CESAR, A.S.; BATALHA, M.O. Biodiesel production from castor oil in Brazil: A difficult reality. Energy Policy, v.38, p.4031-4039, 2010.

CEZAR, M.F.; SOUZA, W.H. Carcaças ovinas e caprinas: obtenção, avaliação, tipificação. 1.ed. João Pessoa: Editora da UFCG, 2007. $131 \mathrm{p}$.

GABRIELLA, P.P.A.G.; ANDRÉ, S.L.F.; PAULO, A.Z.S. History and policy of biodiesel in Brazil. Energy Policy, v.35, p.5393-5398, 2007.

GARCIA, C.G.; MONTEIRO, A.L.G.; COSTA, C. et al. Medidas objetivas e composição tecidual da carcaça de cordeiros alimentados com diferentes níveis de energia em creep feeding. Revista Brasileira de Zootecnia, v.32, p.1380-1390, 2003.

GERRARD, D.E.; GRANT, A.L. Principles of animal growth and development. Kendall: Hunt Publishing Company, 2006. 264p.

HUIDOBRO, F.R.; CAÑEQUE, V. Produccion de carne em corderos de raza Manchega. III. Composição tisular de las canales y de las piezas. Revista Producción Sanidad Animal, v.9, p.57-69, 1994.

KLOPFENSTEIN, T.J.; ERICKSON, G.E.; BREMER, V.R. BoardInvited Review: Use of distillers by-products in the beef cattle feeding industry. Journal of Animal Science, v.86, p.1223-1231, 2008.

MADRUGA, M.S.; SOUSA, W.H.; ROSALES, M.D. et al. Qualidade da carne de cordeiros Santa Inês terminados com diferentes dietas. Revista Brasileira de Zootecnia, v.34, p.309-315, 2005.

MARQUES, A.V.M.S.; COSTA, R.G.; SILVA, A.M.A. et al. Rendimento, composição tecidual e musculosidade da carcaça de cordeiros Santa Inês alimentados com diferentes níveis de feno de flor-de-seda na dieta. Revista Brasileira de Zootecnia, v.36, p.610-617, 2007.

MENDIETA-ARAICO, B.; SPÖRNDLY, R.; REYES-SANCHÉS, N. et al. Moringa (Moringa oleifera) leaf meal as a source of protein in locally produced concentrates for dairy cows fed low protein diets in tropical areas. Livestock Science, v.137, p. 10-17, 2011.

MOLINA-ALCAIDE, E.; YÁNES-RUIZ, D.R. Potential use of olive by-products in ruminant feeding: A review. Livestock Science, v.147, p.247-264, 2008 .

NATIONAL RESEARCH COUNCIL - NRC. Nutrient requirements of domestic animals: Nutrient requirements of sheep. 6.ed. Washington, D.C.: National Academy Press, 1985. 99p.

OSÓRIO, J.C.S.; OSÓRIO, M.T.M.; SAÑUDO, C. Características sensoriais da carne ovina. Revista Brasileira de Zootecnia, v.38, p.292-300, 2009 (supl. especial).

PÉREZ, J.R.O.; BRESSAN, M.C.; BRAGAGNOLO, N. et al. Efeito do peso ao abate de cordeiros Santa Inês e Bergamácia sobre o perfil de ácidos graxos, colesterol e propriedades químicas. Ciência e Tecnologia de Alimentos, v.22, p.11-18, 2002.

PINHEIRO, R.S.B. Aspectos quantitativos da carcaça e qualitativos da carne de ovinos de diferentes categorias. 2006. $105 f$.
Dissertação (Mestrado em Zootecnia) - Faculdade de Ciências Agrárias e Veterinárias/UNESP, Jaboticabal.

PURCHAS, R.W.; DAVIES, A.S.; ABDULLAH, A.Y. An objective measure of muscularity: changes with animal growth and differences between genetic lines of Southdown sheep. Meat Science, v.30, p.81-94, 1991.

RUSSO, C.; PREZIUSO, G.; CASAROSA, L. et al. Effect of diet energy source on the chemical-physical characteristics of meat and depot fat of lambs carcasses. Small Ruminant Research, v.33, p.77-85, 1999.

SANTOS SILVA, J.; MENDES, I.A.; BESSA, R.J.B. The effect of genotype, feeding system and slaughter weight on the quality of light lambs 1 . Growth, carcass composition and meat quality. Livestock Production Science, v.76, p.17-25, 2002.

SAÑUDO, C.; SANTOLARIA, M.P.; MARÍA, G. et al. Influence of carcass weight on instrumental and sensory lamb meat quality in intensive production systems. Meat Science, v.42, p.195-202, 1996.

SIERRA, I. Contributions to the study Blanco Belga $\mathrm{x}$ Landrace: productive characteristics of the channel and the meat quality. Revista del Instituto de Economia y Producciones Ganaderas del Ebro, v.16, p.43, 1973.

SILVA, M.S.; MACEDO, L.C.; SANTOS, J.A.B. et al. Exploitation of co-products of biodiesel production chain of castor oil. Exacta, v.8, p.279-288, 2010.

SILVA SOBRINHO, A.G. Body composition and characteristics of carcass from lambs of different genotypes and ages at slaughter. Palmerston North: Massey University, 1999. 54p. Report (Post Doctorate in Sheep Meat Production).

SILVA SOBRINHO, A.G.; PURCHAS, R.W.; KADIM, I.T. et al. Características de qualidade da carne de ovinos de diferentes genótipos e idades ao abate. Revista Brasileira de Zootecnia, v.34, p.1070-1078, 2005a.

SILVA SOBRINHO, A.G.; PURCHAS, R.W.; KADIM, I.T. et al Musculosidade e composição da perna de ovinos de diferentes genótipos e idades ao abate. Pesquisa Agropecuária Brasileira, v.40, p.1129-1134, 2005 b.

TEIXEIRA, E.; MEINERT, E.; BARBETTA, P.A. Análise sensorial dos alimentos. Florianópolis: Editora da UFSC, 1987. 102p.

VIEIRA, T.R.L.; CUNHA, M.G.G.; GARRUTTI, D.S. et al. Propriedades físicas e sensoriais da carne de cordeiros Santa Inês terminados em dietas com diferentes níveis de caroço de algodão integral (Gossypium hirsutum). Ciência e Tecnologia de Alimentos, v.30, p.372-377, 2010.

WEISS, W.P. Energy prediction equations for ruminant feeds. In: CORNELL NUTRITION CONFERENCE FEED MANUFACTURES, 61., 1999, Ithaca. Proceedings... Ithaca: Cornell University, 1999. p.176-185.

WHEELER, T.T.; CUNDIFF, L.V.; KOCH, R.M. Effects of marbling degree on palatability and caloric content of beef. Beef Research Progress Report, v.71, p.133-134, 1993.

ZAPATA, J.F.F.; NOGUEIRA, C.M.; SEABRA, L.M.J. et al. Composição centesimal e lipídica da carne de ovinos do nordeste brasileiro. Ciência Rural, v.31, p.691-695, 2001. 